\title{
Investigating ESP Students' \\ Writing Problems \\ The case of the management school of Tlemcen
}

Boukhatem Nadera

Ecole Supérieure de management ESMT Tlemcen Algeria

\begin{abstract}
:
Writing is an important skill for language production. However, it is considered as one of the most significant problems that affect not only native English speakers, but also hundreds of students that are learning English as a second or foreign language around the world. Thus, students face many challenges in writing. The fact that students do not have interest in the Composition writing leads them to be poor writers, increase the errors in their homework, write run-on sentences and incoherent paragraphs. Therefore, the present study aims to investigate problems in undergraduate ESP learners' writing and factors that hinder their writing skills. It also aimed at obtaining suggestions on how to improve learners' writing skills. For this purpose, teachers must improve their students writing skills by using effective teaching methods and more reading and writing practice.
\end{abstract}

Key words: Writing, problems, challenges, suggestions, improve 
International Conference on SOCIAL SCIENCE, HUMANITIES \& EDUCATION

\section{1-23 December, 2018 in Berlin - Germany}

\section{Introduction:}

Most of our students who are learning English as a second or a foreign language consider writing as not only the most difficult skill to master, but also a stringent activity. To help them cope these problems, the application of planning in the writing process seems to be a solution. This study attempts to find out how different planning formats can boost ESP students' writing performance in argumentative essays. The result of the study shows that the provision of planning is effective to improve the students' performance in writing argumentative essay. The effectiveness of different types planning depends on the students' preference of which to use. In fact, people are gradually aware of the importance of the writing skill which must be mastered by those who want to be recognized in the global world. It plays a major role in expressing one's ideas, thoughts, opinions, and attitudes.

Writing is used in diaries for expressing personal enjoyment or for some other purposes. More than that, taking notes for students is another example of writing for one's self. It makes their thoughts visible and transferable to other people.

Hedge (1988:5) postulates that a good deal of writing in the English language classroom is undertaken as an aid to learning; for example, to consolidate the learning of new structures or vocabulary or to help students remember new items of language.

It assists them to have a chance to adventure with the language, to go beyond what they have learned (Raimes, 1983).

It allows teachers to behold students and identify problems encountered. This shows that writing plays a predominant role in language learning .Since English is a more widespread international language for business and higher education.

Ismail (2011) pointed out that English writing bears chances for students to think critically and gives the inspiration to learn certain parts of academic writing like utilizing powerful word expressions and a great vocabulary.

Writing in the mother tongue is painful for many students, but when it comes to writing in the second language the students' hardship and pain are worsen (Gilmore, 2009).

\section{Aim and research questions:}

The aim of this paper is to scrutinize how English teachers work with their students' writing problems in the classroom, and also how they perceive these writing difficulties. This study paper also aims to see how the teachers genuinely deal with this issue during their lessons. The purpose is summarized in the following questions: 


\section{International Conference on SOCIAL SCIENCE, HUMANITIES \& EDUCATION}

\section{1-23 December, 2018 in Berlin-Germany}

1. What are the writing problems encountered by English foreign language learners?

2. What are the factors that may cause difficulties in the academic writing?

3. what are the teachers' perceptions towards dealing with writing difficulties?

4. How do the teachers deal with writing difficulties in the classroom?

\section{Problems faced by the Students:}

The study examines the problems that postgraduate students face. It also deals with the mistakes that they make in writing short paragraphs according to their fields of work (Management). Students face many problems when paraphrasing. For instance, students are impotent of using their own words or reconstruct sentences based on their own critical thinking, and formulate sentences in a more effective way. More than that, students interfere their native language (Arabic language).They usually write in English and think in Arabic or French . One could say that students are incapable of constructing the functions of writing, the process of paraphrasing in making new word structure based on their own perspectives without changing the meaning of the words. Most students commit many mistakes related to sentence structure. For Instance, grammatical, syntactical mistakes are effectuated.

Writing in the mother tongue is painful for many students, but when it comes to writing in the second language the students' hardship and pain are worsen (Gilmore, 2009).

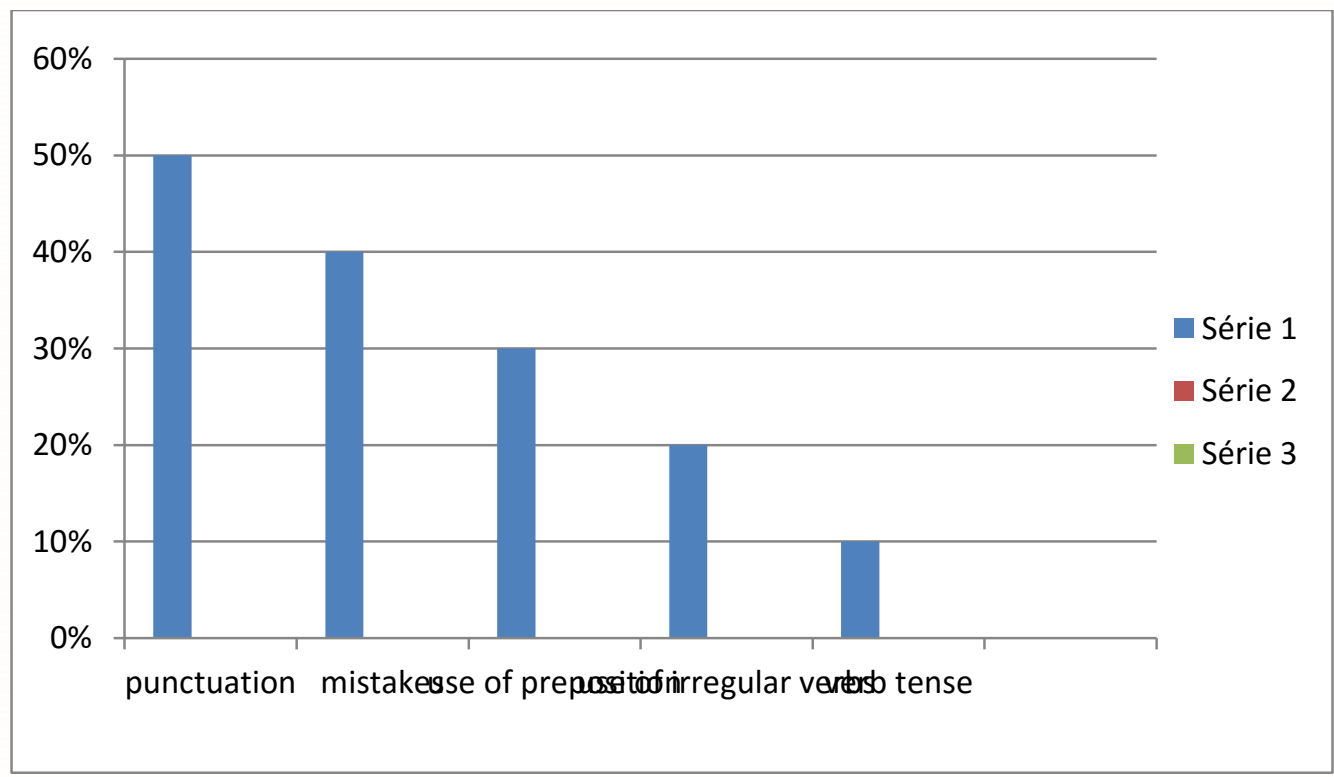


International Conference on SOCIAL SCIENCE, HUMANITIES \& EDUCATION

\section{1-23 December, 2018 in Berlin - Germany}

\section{Research Instruments and Data Analysis:}

The primary intention of this study was to investigate the challenges of scholastic writing which students of English as ESP undergraduate learners had to encounter. This finding matched with Hutchinson \& Waters (1987) who also strongly suggested that it is important to acquaint the learners with the use of punctuation for smooth progression in scholarly writing. The "use of irregular verbs"e is another difficulty for the learners who confused between the use of the past and the past participle forms of irregular verbs.

Similarly "As verbs take different forms depending on tense and subjects they are used with, they create problems for second language writing students" (Tyner, 1987).

The findings also, revealed the problems of inappropriate use of prepositions which is a major kind of error found in the academic writings students (Al-Khairy, 2013).

Kharma (1987) states that students have problems with subject verb agreements, pronoun references, and connectors.

\section{CAUSES OF LEARNERS’ PROBLEMS IN WRITING}

\section{The written medium:}

Writing is an extremely complex activity for the students who used general English (in the secondary school) in a simple way rather than complex economical words (management school). They must be vigilant with the format, sentence structure, vocabulary and punctuation.

Grabe and Kalan (1996:6) think that since writing does not come naturally but rather gained through continuous effort and much practice, it becomes a complex skill. Norish (1993) states the following about the complexity of writing.

In written medium, information has to be transmitted without any aid from sources other than the language itself. It seems to follow from this that more attention is needed to be paid to the language as a code in short to the grammatical and lexical system than is the case with speech.(p.65)

Furthermore, in spite of the fact that English is a foreign language in Algeria only one session during the week is devoted to English for all the grades. On the other hand, it is also noteworthy that in most universities, teaching English involves large classes (Rashidi, 1995) and limited school facilities and learning materials Sa"eadat"es (1998).

\section{Lack of Intrinsic Motivation among learners:}

It is noteworthy that the lessons presented by teachers focus on the grammars, English passages and the textbooks are too long. 


\title{
International Conference on SOCIAL SCIENCE, HUMANITIES \& EDUCATION
}

\author{
21-23 December, 2018 in Berlin-Germany
}

That is why nearly $50 \%$ of the participants mentioned that English was the FL that they preferred the most, even though French is of major importance in the majority of job sectors in Algeria. This clarifies that the students were aware of the importance of FLs just like what was discovered in Chambers' (1993) study, who reported that most of pupils claimed that learning an FL was important or quite important.

According to Zamel (1997) the writing class should take into account the learners' purposes for writing. Writing tasks can be developed rapidly when students' concerns and interests are acknowledged, when they are given numerous opportunities to write and when they are encouraged to become participants .

Silva (1990) believes that it is both 'reasonable and motivating' to allow students to choose their own topics and that when students are allowed this freedom, their work is more successful.

\section{Inadequate Time :}

Students perceived that the time spent to practice writing in class was insufficient for them to improve on their writing. They claim that the time spent in learning to write in which was around one hour and half a week was insufficient for them to be a good writer. Therefore, they insisted that they needed more practice time outside of class time in order to improve. Hedge (1988: 11) states that the idea of time needs to be given attention because writing activities by nature have different stages which need ample time. In line with this, White and Arndt (1991) in Italo (1999: 47) state that "time is needed to incubate, sift and shape ideas.

Time may also be an important factor in producing a text with full of control over organization and coherence. In addition, many students and teachers feel that writing under time pressure is a very unnatural situation and perhaps cannot lead them to produce compositions that are truly representative of their capabilities (Kroll, 1990: 140).

\section{Conclusion:}

It can be concluded that ESP students need more improvement on English language proficiency and language use. Teachers must provide them with more exercises to develop their writing skill. Additionally, they should train ESP students seriously in order to improve and develop either their language proficiency or their writing skill .So that they complete writing assignments successfully in a more sophisticated planning strategy. 
International Conference on SOCIAL SCIENCE, HUMANITIES \& EDUCATION

\section{1-23 December, 2018 in Berlin-Germany}

\section{References}

Al-Khairy, M. H. (2013). English as a foreign language learning demotivational factors as perceived by Saudi undergraduates. European Scientific Journal, 9(32).

Chambers, G. (1993). Taking the 'de' out of demotivation. Language Learning Journal, 7, 1316.

Gilmore, A. (2009). Using online corpora to develop students' writing skills. ELT Journal, 63(4), 363-372.

Grab, W. and Kalan, R.(1996).Theory and Practice of Writing. London: Addison Wesley Longman.

Hedge, T. (1988). Writing. Oxford: Oxford University Press.

Hutchinson, T., \& Waters, A. (1987). English for specific purposes. Cambridge: Cambridge University Press.

Kharma. N. 1987. 'Arab Students' Problems with the English Relative Clause'. IRAL 25/3: 257-266.

Norrish, J. (1983). Language Learners and their Errors. London. Mac Millan Publishers.

Raimes, A. (1983). Techniques in Teaching Writing. Oxford:

Rashidi, N. (1995). Teaching and learning English in Kurdistan province: Problems and Solutions. MA Thesis, Shiraz University. Shiraz, Iran . Available online: www.irandoc.ir

Sa adat, M. (1998). An investigation of problems in teaching and learning English in Junior high-schools of Fars Province. MA Thesis, Shiraz University, Shiraz, Iran. Available online: www.irandoc.ir

Silva, T. (1990). 'Second Language Composition Instruction.Development, Issues and Dissections in ESL'. In B, Kroll (ed). Second Language Writing: Research Insights for the Classroom.

Tyner, E. (1987). College Writing Basics: A Progressive Approach. Belmont. Wands worth Publishing Company.

White, R. and V. Arndt. (1991). Process Writing. London. Longman.

Zamel, V. (1985) "Responding to student writing." TESOL Quarterly 19 : 79-101. 